\title{
SOCIAL PHILOSOPHY AND POLICY
}

\section{Edited by Ellen Frankel Paul}

Each 192-page issue of Social Philosophy and Policy is devoted to a single topic in social or political philosophy, with specially invited papers (and, for designated issues, unsolicited papers) by leading scholars on the most important issues of our time. The topics for Volume 5 are Equal Opportunities and $A n$ Examination of David Gauthier's Morals by Agroement. Previous issues have focussed on Distributive Justice. Human Rights, Liberty and Equality, Ethics and Economics, Nuclear Rights/Nuclear Wrongs, Marxism and Liberalism, Philosophy and Law, and Beneficence, Philanthropy and the Public Good, with contributions from such distinguished philosophers as Maurice Cranston, Ronald Dworkin, R. M. Hare, David Gauthier, J. R. Lucas, Amartya Sen, Jon Elster, and G. A. Cohen, among others.

Recent articles include:

Capitalism, Justice and Equal Starts

HILLEL STEINER

The Justification of Equal Opportunity

ALAN H. GOLDMAN

The Gauthier Enterprise

JAMES M. BUCHANAN

Rationality in Agreement

GILBERT HARMAN

Social Philosophy and Policy is published in October and April for the Social Philosophy and Policy Center, Bowling Green State University, USA Subscription to Volume 5, 1988 Individuals: $₹ 12.00$ (UK) $\Sigma 13.60$ (overseas) US $\$ 16.35$ (N. America) Institutions: $£ 29.00$ (UK) £36.00 (overseas) US $\$ 50.00$ (N. America)

$\square$ Please enter my subscription to Social Philosophy and Policy/send me a sample copy

$\square$ I enclose cheque/money order made payable to Basil Blackwell

Please charge my Access/American Express/Barclaycard/Diners Club/ Mastercharge/Nisa account number:

Signature

Card expiry date

For payments via the National Giro Bank, the Basil Blackwell account number is 2366053

Address

If address registered with card company differs from above, please give details. Please return this form together with your payment if applicable to:

Basil Blackwell - Journals Subscription Dept., 108 Cowley Road, Oxford OX4 1JF, UK or Journals Dept., Box 1320, Murray Hill Station, NY 10156, USA. 


\section{CONTRIBUTORS}

N. Scott Arnold is Assistant Professor of Philosophy at the University of Alabama at Birmingham. He has published articles on ethics and economics in Ethics and The Canadian Journal of Philosophy. Currently, he is writing a book on Marx's radical critique of capitalism.

James M. Buchanan is General Director of the Center for Study of Public Choice and Professor at George Mason University. Winner of the Nobel Prize in Economic Science in 1986, his recent publications include The Reason of Rules (with Geoffrey Brennan) and Liberty, Market, and State.

Peter J. Hammond is Professor of Economics at Stanford University. He is a Fellow of the Econometric Society and former joint managing editor of The Review of Economic Studies. He has published articles on welfare economics, social choice theory, uncertainty, limited information, and decision theory.

Jerry S. Kelly is Professor of Economics at Syracuse University. He is author of Arrow Impossibility Theorems and Social Choice Theory. His current research interests are rights and social choice, computational complexity of social choice, and geometry and voting theory.

Edward F. McClennen is Professor of Philosophy at Washington University in St. Louis and a former Fellow of the National Humanities Center. His Rationality and Dynamic Choice: Foundational Explorations is forthcoming from Cambridge University Press. He is currently working on a book dealing with the connection between rational and moral choice.

Edward McKenna is Assistant Professor of Economics at Connecticut College. His research is in post-Keynesian economics. He has published in The Journal of Post-Keynesian Economics, The Journal of Monetary Economics, and The Cambridge Journal of Economics.

Jonathan Pressler is Assistant Professor of Philosophy at Carnegie-Mellon University. His research interests include metaethics, social choice theory, political philosophy, and international security. At Carnegie-Mellon, he is part of a team that is developing an intelligent, computerized logic tutor.

Louis Putterman is Professor of Economics at Brown University. His research concerns economic systems, organization and incentives, and economic development. He is editor of The Economic Nature of the Firm: A Reader and co-author, with John Bonin, of Economics of Cooperation and the Labor-Managed Economy. 
Teddy Seidenfeld is Professor of Philosophy and Statistics at Carnegie-Mellon University. He is author of Philosophical Problems of Statistical Inference. His research interests include foundational problems in probability, statistics, and decision theory.

Julius Sensat is Associate Professor of Philosophy at the University of Wisconsin at Milwaukee. He is the author of Habermas and Marxism: An Appraisal and several articles on topics in social philosophy and the philosophy of social science.

Keith Tribe is Senior Lecturer in Economics at the University of Keele in Staffordshire, England. His most recent books are Governing Economy: The Reformation of German Economic Discourse 1750-1840 and Reading Weber. His current research interests include commercial education and economics in British higher education, 1890-1940.

Maurice Wade is Assistant Professor of Philosophy at Trinity College in Hartford. His areas of specialization include applied ethics and contemporary social and political philosophy. His research has been in the areas of health care technology, Hume, and the moral status of corporations.

Diane Zannoni is Associate Professor of Economics at Trinity College. Her research is in post-Keynesian economics. She has published in The Journal of Post-Keynesian Economics, The Journal of Monetary Economics, and the American Economic Review. 


\title{
ECONOMICS AND PHILOSOPHY
}

\author{
Volume 4
}

1988

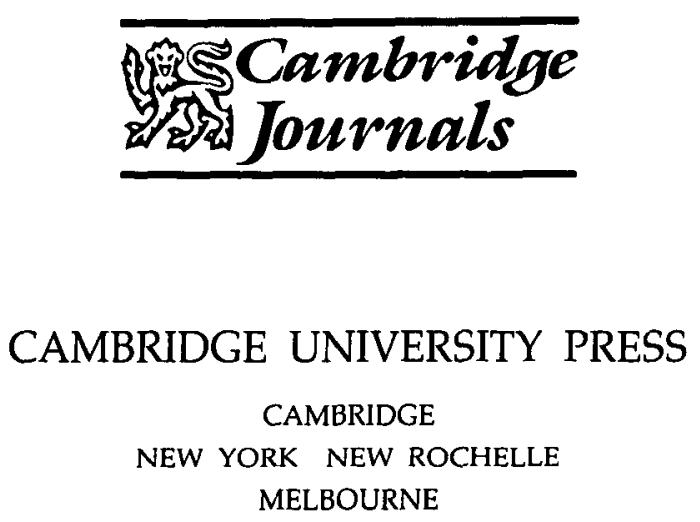




\section{REFEREES FOR ECONOMICS AND PHILOSOPHY}

(July 1,1987 to June 30,1988 )

Albanese, Paul ).

Mayo, Deborah

Alleva, Ernest

Ball, Stephen W.

Bateman, Bradley W.

Bicchieri, Cristina

Binmore, Ken

Broome, John

Carens, Joseph $\mathrm{H}$.

Colander, David

McClennen, Edward

Miller, Roger

Morgenbesser, Sidney

Mumy, Gene E.

Nelson, Alan

Pearce, David

Penz, Peter

Cudd, Ann E.

Pressler, Jonathan

Rappaport, Steven

Daniels, Norman

de Marchi, Neil

Gilboa, David

Goldfarb, Robert

Reder, Melvin

Riley, Jonathan

Schapiro, Morton O.

Schick, Frederic

Gordon, H. Scott

Schweickart, David

Hands, D. Wade

Seidenfeld, Teddy

Kamlet, Mark

Shefrin, Hersh

Karelis, Charles $\mathrm{H}$.

Soltan, Karol

Kincaid, Harold

Streeten, Paul

Koons, Robert

Langlois, Richard

Weintraub, E. Roy

Larmore, Charles

Weirich, Paul

Whitesell, Robert

Levin, Henry

Winston, Gordon

Levine, Andrew

Worland, Stephen

Levine, David

Wright, Erik

Levy, Brian

Zannoni, Diane

Lyon, Paul

Editorial Assistant (1988), Gwen W. Steege 


\section{ECONOMICS AND PHILOSOPHY}

Contents of Volume 4, 1988

Editors' Introduction

HAUSMAN, DANIEL M. Standards 1 MCPHERSON, MICHAEL S.

Essays

BINMORE, KEN

Modeling Rational Players: Part II 9

LEVY, DAVID

Utility-Enhancing Consumption

Constraints 69

MCKENNA, EDWARD

WADE, MAURICE

ZANNONI, DIANE

PUTTERMAN, LOUIS

SEIDENFELD, TEDDY

SEN, AMARTYA

SENSAT, JULIUS

Keynes, Rawls, Uncertainty, and the Liberal Theory of the State 221

The Firm as Association Versus the Firm as Commodity: Efficiency, Rights, and Ownership 243

Decision Theory without "Independence" or without "Ordering": What Is the Difference? 267

Property and Hunger $\mathbf{5 7}$

Methodological Individualism and Marxism 189

Symposium

MÄKI, USKALI

How to Combine Rhetoric and Realism in the Methodology of Economics $\mathbf{8 9}$

MÄKI, USKALI

Realism, Economics, and Rhetoric: A Rejoinder to McCloskey 167

MCCLOSKEY, DONALD N. Two Replies and a Dialogue on the Rhetoric of Economics: Mäki, Rappaport, Rosenberg 150

RAPPAPORT, STEVEN

Economic Methodology: Rhetoric or Epistemology? $\mathbf{1 1 0}$

RAPPAPORT, STEVEN

Arguments, Truth, and Economic Methodology: A Rejoinder to McCloskey $\mathbf{1 7 0}$ 
ROSENBERG, ALEXANDER Economics Is Too Important to Be Left to the Rhetoricians 129

ROSENBERG, ALEXANDER Rhetoric Is Not Important Enough for Economists to Bother About $\mathbf{1 7 3}$

Discussions

ARNOLD, N. SCOTT

Reply to Professor Putterman 337

HAMMOND, PETER J.

Orderly Decision Theory: A Comment on Professor Seidenfeld 292

KELLY, JERRY S.

Rights and Social Choice: Comment 316

MCCLENNEN, EDWARD F. Ordering and Independence: A Comment on Professor Seidenfeld 298

PRESSLER, JONATHAN

How to Avoid the Paretian-Libertarian Paradox: A Reply to Kelly 326

PUTTERMAN, LOUIS Marx and Disequilibrium: Comment 333

SEIDENFELD, TEDDY Rejoinder 309

Reviews

BUCHANAN, JAMES M. Robert Sugden's The Economics of Rights, Cooperation, and Welfare 341

DUMMETT, MICHAEL Jon Elster and Aanund Hylland's (eds.), Foundations of Social Choice Theory 177

SHEPSLE, KENNETH A. Thomas Schwartz's The Logic of Collective Choice 183

TRIBE, KEITH

Richard F. Teichgraeber's "Free Trade" and Moral Philosophy: Rethinking the Sources of Adam Smith's Wealth of Nations 342 


\section{INSTRUCTIONS FOR CONTRIBUTORS}

Contributions and editorial correspondence should be sent to Economics and Philosophy, Department of Economics, Fernald House, Williams College, Williamstown, MA 01267, U.S.A. The journal's editorial office may also be accessed at BITNET address

MLSTEEGE@WILLIAMS

or at ARPANET address

MLSTEEGE@VAX.CS.WILLIAMS.EDU.

Please use for correspondence only. Authors should send four copies of their manuscript and reserve one copy for their use in checking proofs. Articles must be in English. Spelling, capitalization, and punctuation must be consistent within each article and conform with the Thirteenth Edition of The Chicago Manual of Style (University of Chicago Press).

Preparation of manuscript. A separate title page should be prepared carrying the article title, auxiliary short title (not over 50 characters), author's full name (in the form preferred for publication), and author's affiliation (including full mailing address and phone number). Because blind reviewing will be employed, authors are asked to identify themselves only on the title page.

The entire manuscript (including notes and references) should be typed doublespaced on $8 \frac{1}{2}$ by 11 inch or A4 paper, with wide margins for copy editing. Manuscript pages should be numbered consecutively.

Figures. If the manuscript is accepted for publication, the author must provide figures that are ready for photographic reproduction; they cannot be redrawn by the printer, unless the author pays for the cost of such work. Charts, graphs, or other artwork must be drawn by a professional artist or computer-generated on a Laser printer in black ink on white paper and should remain legible after a $50 \%$ reduction. All labels and details on figures should be clearly printed (or done in transfer type of a sans-serif face such as Helvetica).

References and notes. Bibliographic citations in the text must include the author's last name and the date of publication and may include page references: for example, (Bryant, 1980, pp. 335-44). When an author's name is part of the text, the following form should be used: "Bryant (1980, pp. 335-44) maintained that . . ." When a work by two or more authors is referred to, all names should be given in the first citation: for example,
(Kravis, Heston, and Summers, 1978), with subsequent citations of the form (Kravis et al., 1978). When separate works are referred to within the same parentheses, they should be listed in alphabetical order. Those by the same author should be separated by commas and those by different authors by semicolons: for example, (Fuss and McFadden, 1978; Georgescu-Roegen, 1971，1976).

Complete bibliographic information for each citation should be included in the list of references. References should be typed in alphabetic order using the style of the following examples:

Arrow, Kenneth J. 1974. The Limits of Organization. New York: Norton.

Bryant, John. 1980. "A Model of Reserves, Bank Runs, and Deposit Insurance." Journal of Banking and Finance 4:355-64.

Fuss, Melvyn, and McFadden, Daniel (editors). 1978. Production Economics: $A$ Dual Approach to Theory and Applications. Amsterdam: North Holland.

Georgescu-Roegen, 1976. "Chamberlain's New Economics and the Unit of Production." In Monopolistic Competition Theory: Studies in Impact, edited by Robert E. Kuenne, pp. 31-62. New York: Wiley.

Titles of journals should not be abbreviated.

When more than an in-text citation is called for, footnotes may be used. These should be numbered consecutively throughout the text and typed at the bottom of the page in which they are cited. Source citations within footnotes follow the same style as citations in text.

Copyediting and proofreading. The publishers reserve the right to copyedit and proofread all articles accepted for publication, but authors will be consulted in the case of any substantial changes. Page proof of article will be sent to the lead author for correction of typographical errors only.

General. The lead author will receive 25 offprints of his or her article free of charge; additional numbers may be purchased if ordered at proof stage. Submission of an article implies that it has not been published elsewhere. Authors are responsible for obtaining written permission to publish material for which they do not own the copyright. Contributors will be asked to assign their copyrights, on certain conditions, to Cambridge University Press. 


\title{
ECONOMICS AND PHILOSOPHY
}

\author{
Volume 4 , Number 2
}

\section{Essays}

Julius Sensat

Edward McKenna

Maurice Wade

Diane Zannoni

Louis Putterman

Teddy Seidenfeld

\section{Discussions}

Peter J. Hammond

Edward F. McClennen

Teddy Seidenfeld

Jerry S. Kelly

Jonathan Pressler

Louis Putterman

N. Scott Arnold

\section{Reviews}

James M. Buchanan

Keith Tribe
Methodological Individualism and Marxism 189

Keynes, Rawls, Uncertainty, and the Liberal Theory of the State 221

The Firm as Association Versus the Firm as

Commodity: Efficiency, Rights, and

Ownership 243

Decision Theory without "Independence" or without "Ordering": What Is the Difference? 267

Orderly Decision Theory: A Comment on Professor Seidenfeld 292

Ordering and Independence: A Comment on Professor Seidenfeld 298

Rejoinder 309

Rights and Social Choice: Comment 316

How to Avoid the Paretian-Libertarian Paradox: A Reply to Kelly 326

Marx and Disequilibrium: Comment 333

Reply to Professor Putterman 337

Robert Sugden's The Economics of Rights, Co-operation, and Welfare 341

Richard F. Teichgraeber's "Free Trade" and Moral Philosophy: Rethinking the Sources of Adam Smith's Wealth of Nations 342

CC 1988 Cambridge University Press

CAMBRIDGE UNIVERSITY PRESS

The Edinburgh Building, Shaftesbury Road, Cambridge CB2 2RU, England 32 East 57th Street, New York, NY 10022, U.S.A.

10 Stamford Road, Oakleigh, Melbourne 3166, Australia

Printed in the United States of America 